\title{
H5N2 Highly Pathogenic Avian Influenza Viruses from the US 2014-2015 outbreak have an unusually long pre-clinical period in turkeys
}

\author{
Erica Spackman*, Mary J. Pantin-Jackwood, Darrell R. Kapczynski, David E. Swayne and David L. Suarez
}

\begin{abstract}
Background: From December 2014 through June 2015, the US experienced the most costly highly pathogenic avian influenza (HPAl) outbreak to date. Most cases in commercial poultry were caused by an H5N2 strain which was a reassortant with 5 Eurasian lineage genes, including a clade 2.3.4.4 goose/Guangdong/1996 lineage hemagglutinin, and 3 genes from North American wild waterfowl low pathogenicity avian influenza viruses. The outbreak primarily affected turkeys and table-egg layer type chickens. Three isolates were selected for characterization in turkeys: the US index isolate from December 2014 (A/northern pintail/WA/40964/2014), and two poultry isolates from April 2015 (A/chicken/IA/13388/2015 and A/turkey/MN/12528/2015).

Results: Four week old broad-breasted white turkeys were inoculated with one of three doses $\left(10^{2}, 10^{4}\right.$ or $10^{6}$ $50 \%$ egg infectious doses $\left[E_{1} D_{50}\right]$ per bird) of each of the isolates to evaluate infectious dose and pathogenesis. The mean bird infectious dose of A/northern pintail/WA/40964/2014 and A/turkey/MN/12528/2015 was $10^{5}$ EID 50 per bird, but was $10^{3}$ EID 50 per bird for A/chicken/IA/13388/2015, suggesting the latter had greater adaptation to gallinaceous birds. All three isolates had unusually long mean death time of 5.3-5.9 days post challenge, and the primary clinical signs were severe lethargy and neurological signs which started no more than $24 \mathrm{~h}$ before death (the average pre-clinical period was 4 days). Infected turkeys also shed high levels of virus by both the oropharyngeal and cloacal routes.
\end{abstract}

Conclusions: The unusually long mean death times, high levels of virus in feces, and increased adaptation of the later viruses may have contributed to the rapid spread of the virus during the peak of the outbreak.

Keywords: Highly pathogenic avian influenza virus, Clade 2.3.4.4 H5N2, Turkey disease, Avian influenza outbreak, Chicken disease

\section{Background}

An H5 HPAIV outbreak that began in December 2014 and lasted 6 months through June 2015 was the 5th highly pathogenic avian influenza virus (HPAIV) outbreak in the US since the 1920's and was the most geographically widespread. Direct and indirect costs to the US economy were estimated to be near $\$ 3.3$ billion USD [1]. The hemagglutinin (HA) gene was determined to belong to clade 2.3.4.4 of the goose/Guangdong/1996

\footnotetext{
* Correspondence: Erica.spackman@ars.usda.gov

Southeast Poultry Research Laboratory, USDA-Agricultural Research Service,

934 College Station Rd, Athens, GA 30605, USA
}

(GS/GD/96) H5 lineage of HPAIV and was subsequently named intercontinental group A (IcA) H5 $[2,3]$. Wild waterfowl are thought to have carried viruses of this Eurasian lineage from Asia into North America during migration over the Bearing sea route $[2,4-6]$. The GS/ GD/96 lineage has circulated in wild and domestic birds throughout Asia since 1996 with occasional incursions into Europe and Africa. In December 2014, the IcA H5 HPAIVs were first discovered in poultry in Canada, and subsequently in the US a few weeks later $[4,7]$.

In North America four variants of the IcA $\mathrm{H} 5$ viruses were identified; an H5N8 with a genome that was

(c) The Author(s). 2016 Open Access This article is distributed under the terms of the Creative Commons Attribution 4.0 International License (http://creativecommons.org/licenses/by/4.0/), which permits unrestricted use, distribution, and reproduction in any medium, provided you give appropriate credit to the original author(s) and the source, provide a link to the Creative Commons license, and indicate if changes were made. The Creative Commons Public Domain Dedication waiver (http://creativecommons.org/publicdomain/zero/1.0/) applies to the data made available in this article, unless otherwise stated. 
completely Eurasian in lineage ( $\geq 98 \%$ identity among all gene segments with $\mathrm{H} 5 \mathrm{~N} 8$ virus isolates from South Korea); and three reassortants with a mixture of North American wild bird lineage genes, an $\mathrm{H} 5 \mathrm{~N} 2$, an $\mathrm{H} 5 \mathrm{~N} 1$ and an H5N8 $[4,8,9]$. The H5N2 was the variant that caused the most cases in commercial poultry in the US [10]. Turkey farms had the highest number of infected premises (153 of 211) during this outbreak, but table-egg layer chickens were the poultry type with the highest numbers of birds affected [10]. The goal of these studies was to characterize the pathobiology of the US index H5N2 HPAIV isolate collected from a wild Northern Pintail in December 2014 and to compare that with two poultry isolates from later in the outbreak (April 2015) in commercial broad breasted white turkeys.

\section{Methods}

\section{Turkeys}

Broad-breasted white turkeys were obtained from a commercial turkey producer and were reared in a commercial production environment from hatch until they were delivered to the Southeast Poultry Research LaboratoryUSDA-ARS (SEPRL) at 4 weeks of age. Each bird was individually tagged for identification. The turkeys were housed and cared for in accordance with procedures approved by the SEPRL Institutional Animal Care and Use Committee. Serum was collected from turkeys immediately prior to challenge to confirm the absence of antibody to type A influenza by commercial ELISA (MultiS Screen, IDEXX Inc. Westbrook, ME).

\section{Viruses}

Three H5N2 HPAIV isolates were selected for evaluation: the US index H5N2 HPAIV isolate from December 2014, A/Northern Pintail/Washington/40964/2014 (NOPI/40964); and two isolates from commercial poultry operations collected in April 2015, A/turkey/MN/12582/ 2015 (TK/12582) and A/chicken/IA/13388/2015 (CK/ 13388). Viruses were provided by the National Veterinary Services Laboratories-USDA-APHIS (Courtesy of Dr. Mia Torchetti). Each isolate was passaged twice in embryonating chickens eggs (ECE) and titrated using standard procedures [11]. Inocula were diluted to the appropriate dose in brain heart infusion (BHI) broth.

\section{Pathogenesis, infectious dose and transmission}

To evaluate the infectious dose of each isolate and transmission to non-inoculated hatch-mates housed in the same isolator (contact exposed turkeys), three doses of virus: $10^{2}, 10^{4}$ and $10^{6} 50 \%$ egg infectious doses ( $\left.\mathrm{EID}_{50}\right)$ per bird, were administered to groups of five turkeys as reported in Bertran et al. [12]. Virus was administered using a simulated respiratory route, the intrachoanal route, in $0.1 \mathrm{ml}$ per bird. The contact exposed turkeys $(n=3)$ were added to each dose group $24 \mathrm{~h}$ post challenge (PC). Sixteen additional turkeys at the $10^{6} \mathrm{EID}_{50}$ per bird dose group were included to characterize the pathogenesis of the virus. Clinical signs and mortality were recorded a minimum of daily and birds that were euthanized due to severe illness were counted as dying the following day for mean death time (MDT) calculations. Turkeys were considered infected if virus was detected in oropharyngeal $(\mathrm{OP})$ or cloacal $(\mathrm{CL})$ swabs at any time point and/or if the bird seroconverted by the end of the experiment (14 days PC).

The later experiments with TK/12582 and CK/13388 had a modified swab collection schedule from what was done with NOPI/40964 because additional sample collection times were added to more precisely establish when the turkeys started to shed detectable levels of virus. For all three isolates, OP and CL swabs were collected from the directly inoculated turkeys at 2, 4, 7, 10 and 14 days $\mathrm{PC}$, and $\mathrm{OP}$ and $\mathrm{CL}$ swabs were collected from contact exposure turkeys at 1, 3, 6, 9 and 13 days PC. Additional OP and CL samples collected from groups inoculated with TK/12582 and CK/13388 were at 12, 24 and $36 \mathrm{~h}$ PC. Virus titers in swabs were evaluated by quantitative realtime RT-PCR. Sera were collected from all surviving turkeys 14 days PC. Sera were tested for antibody by homologous hemagglutination inhibition (HI) assay.

Two to six birds at the $10^{6}$ EID $_{50}$ per bird dose group exposed to each virus were necropsied for tissue collection when clinical signs were apparent. A full set of tissue samples (lungs, bursa, kidneys, adrenal gland, thymus, bursa, brain, liver, heart, proventriculus, pancreas, intestine, spleen, trachea, Harderian gland, beak, and thigh muscle) were collected for microscopic evaluation and immunohistochemistry (IHC). Tissues were fixed in 10\% neutral buffered formalin, sectioned, paraffin embedded, and stained with hematoxylin-and-eosin. Serial sections were stained by IHC methods [13] to visualize influenza antigen in individual tissues. An identical tissue set was collected from two non-inoculated hatch-mates to serve as negative controls.

Sera were collected from all surviving turkeys 14 days PC to evaluate infection status by antibody detection with homologous HI assay.

The infectious dose was calculated by the Reed-Muench method [14], using the criteria that turkeys were considered infected if they had clinical signs, died, shed virus or were positive for antibody 14 days PC.

\section{Quantitative real-time RT-PCR}

Quantitative real-time RT-PCR targeting the influenza $M$ gene including the RNA extraction, was conducted as previously described [15]. The standard curve was run in duplicate using RNA from the same virus stock used to 
prepare the inocula. Virus quantity was reported as equivalents to infectious titer.

\section{Hemagglutination inhibition assay}

The HI assay was conducted using standard procedures [11]. Homologous isolates were used as antigens and were inactivated with $0.1 \%$ beta-propiolactone. A titer of 1:16 $\left(2^{4}\right)$ or above was considered positive.

\section{Statistics}

Virus titers shed by time point for the same swab type (OP or $\mathrm{CL}$ ) were tested among the viruses with KruskalWallis $\mathrm{H}$ test (Prism 7, GraphPad Software, La Jolla, CA). A $p$ value of $\leq 0.05$ was considered significant.

\section{Results}

\section{Infectious dose and transmission}

Infection status was determined based on virus shed, clinical disease, mortality and seroconversion. Turkeys which survived to 14 days were not infected as indicated by lack of virus shed and seroconversion. At each dose and virus combination either 100\% of the turkeys were infected or none were infected (Table 1). The $50 \%$ turkey infectious dose $\left(\mathrm{TID}_{50}\right)$ and $50 \%$ turkey lethal doses $\left(T_{L} D_{50}\right)$ were the same for each isolate and were approximately $10^{5} \mathrm{EID}_{50} /$ bird for $\mathrm{NOPI} / 40964$ and TK/12582 but was two $\log _{10}$ lower for CK/13388 which was $10^{3} \mathrm{EID}_{50}$ /bird (Table 1).

Infection rates in the contact exposure groups were the same as the inoculated groups to which they were exposed; $100 \%$ of the contact exposure turkeys, with all three isolates, at $10^{6} \mathrm{EID}_{50} /$ bird dose group were infected. The only lower dose group where the contact turkeys were infected was the $10^{4} \mathrm{EID}_{50} / \mathrm{bird}$ dose group exposed to $C K / 13388$, where $100 \%$ (3 of 3 ) were infected. All the infected contact exposed birds presented with clinical signs similar to the inoculated turkeys and died.

\section{Virus shed}

No turkeys exposed to $10^{2} \mathrm{EID}_{50} /$ bird shed detectable levels of virus at any time. Only one group exposed to $10^{4} \mathrm{EID}_{50} /$ bird shed detectable levels of virus: the $\mathrm{CK} /$ 13388 exposed group (Table 1). In this group, virus was only detected in OP swabs from 3 of 5 turkeys and in CL swabs from 2 of 5 turkeys, although the two turkeys from which virus was not detected both presented with clinical signs consistent with HPAIV and died (one at $24 \mathrm{~h} P C$ and the other at 5 days PC).

Oro-pharyngeal and CL shed titers for groups exposed to $10^{6} \mathrm{EID}_{50} /$ bird are shown in Fig. 1. Oro-pharyngeal shedding was detectable at all times and peaked 3-4 days PC for all three isolates with titers exceeding $10^{6} \mathrm{EID}_{50} / \mathrm{ml}$ from birds exposed to TK/12528 and CK/13388. Although

Table 1 Mortality, mean death time, 50\% infectious dose, 50\% lethal dose and number of birds shedding for three H5N2 highly pathogenic avian influenza viruses in 4-week old directly inoculated and contact exposed broad-breasted white turkeys

\begin{tabular}{|c|c|c|c|c|c|c|c|c|c|c|}
\hline \multirow[t]{2}{*}{ Isolate } & \multirow[t]{2}{*}{$\begin{array}{l}\text { Dose } \\
\left(\text { ElD }_{50} / \text { bird }\right)\end{array}$} & \multicolumn{2}{|l|}{ Mortality } & \multicolumn{2}{|l|}{$\begin{array}{l}\text { Mean death } \\
\text { time (days) }\end{array}$} & \multicolumn{2}{|c|}{$\begin{array}{l}\text { Number of turkeys } \\
\text { shedding }\end{array}$} & \multicolumn{2}{|c|}{ Seroconversion } & \multirow[t]{2}{*}{$\begin{array}{l}50 \% \text { Turkey } \\
\text { infectious dose }\end{array}$} \\
\hline & & Inoculated & $\begin{array}{l}\text { Contact } \\
\text { exposed }\end{array}$ & Inoculated & $\begin{array}{l}\text { Contact } \\
\text { exposed }\end{array}$ & Inoculated & $\begin{array}{l}\text { Contact } \\
\text { exposed }\end{array}$ & Inoculated & $\begin{array}{l}\text { Contact } \\
\text { exposed }\end{array}$ & \\
\hline \multirow{4}{*}{$\begin{array}{l}\text { A/northern pintail/WA/ } \\
40964 / 2014\end{array}$} & $10^{2}$ & $0 / 5^{a}$ & $0 / 3^{a}$ & $N A^{b}$ & NA & $0 / 5^{d}$ & $0 / 3^{d}$ & $0 / 5^{i}$ & $0 / 3^{i}$ & \multirow[t]{4}{*}{$10^{5} \mathrm{EID}_{50}^{\mathrm{f}}$} \\
\hline & $10^{4}$ & $0 / 5$ & $0 / 3$ & NA & NA & $0 / 5$ & $0 / 3$ & $0 / 5$ & $0 / 3$ & \\
\hline & $10^{6}$ & $5 / 5$ & $3 / 3$ & $5.3(4-7)^{g h}$ & $7.6(7-8)^{\mathrm{cg}}$ & $5 / 5$ & $3 / 3$ & NA & NA & \\
\hline & $10^{6}$ & $16 / 16$ & NA & & NA & $16 / 16$ & NA & NA & NA & \\
\hline \multirow[t]{4}{*}{ A/turkey/MN/12582/2015 } & $10^{2}$ & $0 / 5$ & $0 / 3$ & NA & NA & $0 / 5$ & $0 / 3$ & $0 / 5$ & $0 / 3$ & \multirow[t]{4}{*}{$10^{5} \mathrm{EID}_{50}$} \\
\hline & $10^{4}$ & $0 / 5$ & $0 / 3$ & NA & NA & $0 / 5$ & $0 / 3$ & $0 / 5$ & $0 / 3$ & \\
\hline & $10^{6}$ & $5 / 5$ & $3 / 3$ & $5.9(3-10)$ & $8.0(6-10)$ & $5 / 5$ & $3 / 3$ & NA & NA & \\
\hline & $10^{6}$ & $16 / 16$ & NA & & NA & $16 / 16$ & NA & NA & NA & \\
\hline \multirow[t]{4}{*}{ A/chicken/IA/13388/2015 } & $10^{2}$ & $0 / 5$ & $0 / 3$ & NA & NA & $0 / 5$ & $0 / 3$ & $0 / 5$ & $0 / 3$ & \multirow[t]{4}{*}{$10^{3} \mathrm{EID}_{50}$} \\
\hline & $10^{4}$ & $5 / 5$ & $3 / 3$ & $5.4(1-7)$ & $9.0(6-10)$ & $3 / 5$ & $3 / 3$ & NA & NA & \\
\hline & $10^{6}$ & $5 / 5$ & $3 / 3$ & $5.6(3-13)$ & $7.6(2-13)$ & $5 / 5$ & $3 / 3$ & NA & NA & \\
\hline & $10^{6}$ & $16 / 16$ & NA & & NA & $16 / 16$ & NA & NA & NA & \\
\hline
\end{tabular}

${ }^{\mathrm{a}}$ Number dead/total

${ }^{\mathrm{b}} N A$ not applicable. Either no mortality or no birds survived for antibody testing

${ }^{c}$ Calculated from the day of placement with the inoculated turkeys

${ }^{\mathrm{d}}$ Number shedding/total

e $50 \%$ infectious dose was equal to the $50 \%$ lethal dose for all isolates

${ }^{\mathrm{f}} \mathrm{EID}_{50}=50 \%$ egg infectious dose

${ }^{9}$ Mean death time days (range of mortality in days). For inoculated birds includes data from all 21 turkeys exposed to $10^{6}$ EID ${ }_{50} / b$ ird

${ }^{\mathrm{h}}$ Mean death times are combined for directly exposed turkeys in the same dose group for each isolate

iNumber seroconverted/total 
A/northern pintail/WA/40694/2014 OP shed

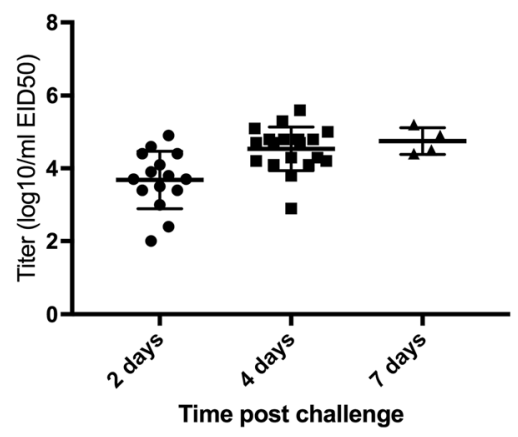

A/turkey/MN/12528/2015 OP shed

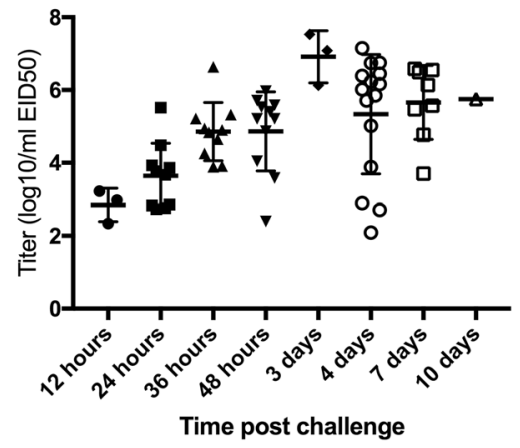

A/chicken/IA/13388/2015 OP shed

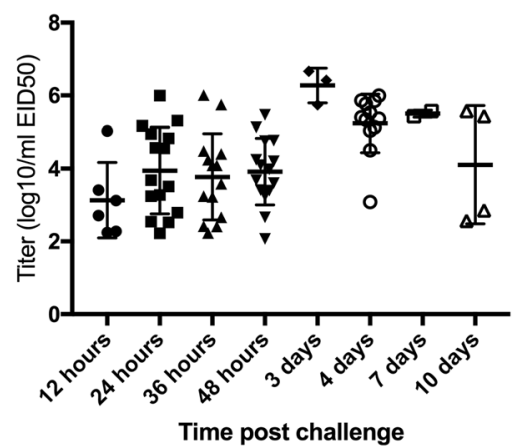

A/northern pintail/WA/40694/2014 CL shed

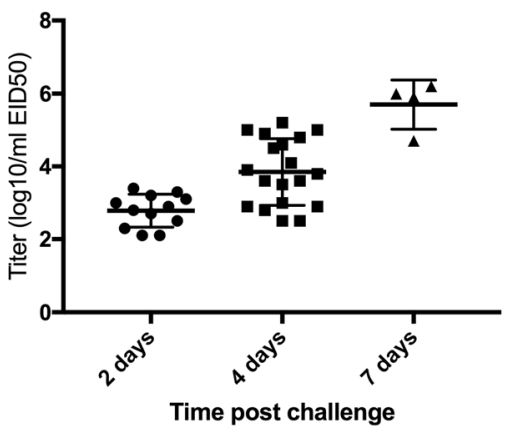

A/turkey/MN/12528/2015 CL shed

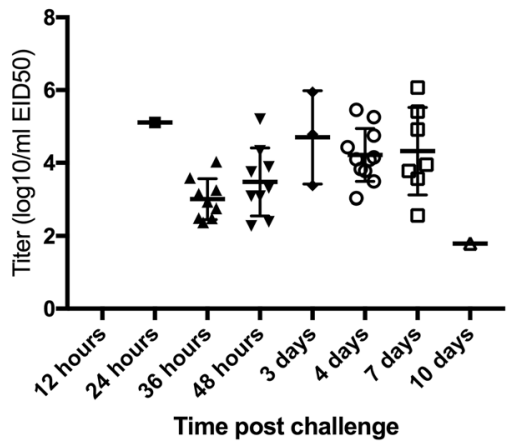

A/chicken/IA/13388/2015 CL shed

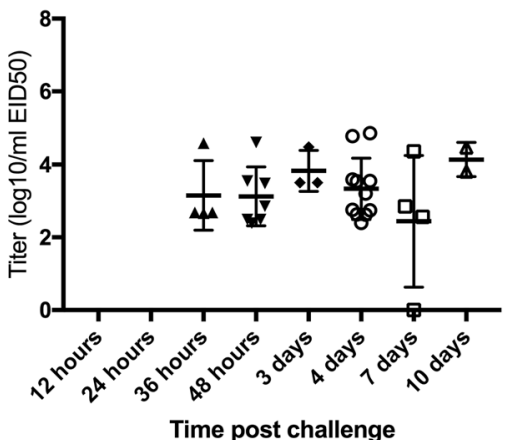

Fig. 1 Oropharyngeal (OP) and cloacal (CL) shed determined by real-time RT-PCR for each virus by time post challenge with $10^{6} 50 \%$ egg infectious doses $\left(E_{1 D_{50}}\right.$ ) per bird. Data are absent from the A/northen pintail/WA/40964/2014 isolates at 12, 24, $36 \mathrm{~h}$ and 3 days because the samples were not collected, at 10 and 14 days because no turkeys survived to these time points. Thick bars indicate the mean of the group and error bars represent one standard deviation

titers from birds exposed to NOPI/40964 were about one $\log _{10}$ lower the difference was not significant. Cloacal shedding also peaked at 3 days PC from birds exposed to TK/12528 and CK/133388, but was later for NOPI/40964 exposed birds where the highest titers were at 7 days PC. Turkeys in the $10^{6} \mathrm{EID}_{50}$ /bird dose group that survived to 10 days PC were still shedding virus. There were no differences in the numbers of turkeys shedding among the isolates for the $10^{6} \mathrm{EID}_{50}$ /bird dose group (all were $100 \%$ ).

Shed titers were compared among all three isolates for all turkeys exposed to $10^{6} \mathrm{EID}_{50} /$ bird by swab type at 2 and 4 days PC and between TK/12582 and CK/13388 at
$12,24,36 \mathrm{~h}$ and $3 \mathrm{DPC}$ (at time points where five or fewer birds were shedding detectable levels of virus statistical analysis was not performed). At $36 \mathrm{~h} \mathrm{PC}$ the OP titers from TK/12528 were significantly lower than CK/ 13388. Titers of shed among the viruses were only significantly different at two other times; CK/13388 OP shed titers were significantly lower than either NOPI/ 40964 or TK/12582 at 2 days PC, and CK/13388 titers were again significantly lower than either other virus with CL at 4 days PC.

Each group of contact exposed turkeys shed virus similarly to the inoculated groups with which they were 
housed. In the groups housed with the $10^{6} \mathrm{EID}_{50} / \mathrm{bird}$ dose group all (3 of 3 ) contact exposure turkeys shed virus. In the $10^{4} \mathrm{EID}_{50}$ /bird dose group for $\mathrm{CK} / 13388$, which was the only middle or lower dose group to be infected; all three turkeys shed virus (data not shown).

\section{Pathogenesis}

The pathogenesis for all three isolates was similar. Mean death times for the inoculated turkeys were between 5.3 and 5.9 days and were between 7.6 and 9 days post placement for the contact exposed turkeys (Table 1). Clinical disease was not apparent until $24 \mathrm{~h}$ or less prior to death (turkeys that could not reach food or water were euthanized). With all three isolates, an average of $50 \%$ of the turkeys died without exhibiting any clinical signs within $12 \mathrm{~h}$ prior to death (i.e. they appeared normal at the late afternoon/evening observation period and were dead at the morning observation period).

The only clinical signs observed were neurological signs and lethargy. Lethargic birds tended to rest with ruffled body feathers. The severity of neurological signs and lethargy was similar among all three isolates. Neurological signs consisting of torticollis (Fig. 2), tremors or ataxia were observed in 28 and $23 \%$ of the turkeys infected with NOPI/40964 and TK/12582, and $50 \%$ of the turkeys infected with CK/13388.

Turkeys were selected for necropsy because they were presenting with clinical signs (neurological and/or lethargy). Tissues were collected from six turkeys exposed to NOPI/40964 (4 DPC) and from two turkeys exposed to TK/12582 and two turkeys exposed to CK/13388 (3DPC). Gross lesions were typically absent, however petechial hemorrhages were observed in the skeletal muscle of two

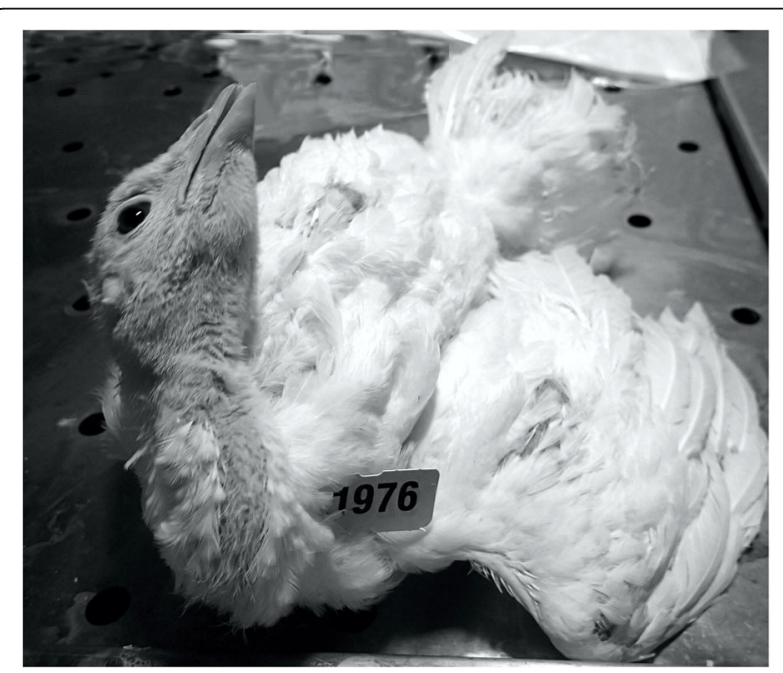

Fig. 2 Four week-old broad-breasted white turkey with torticollis after exposure to A/northern pintail/WA/40964/2014 H5N2 highly pathogenic avian influenza virus turkeys: one infected with TK/12582 and CK/13388 each. The CK/13388 infected turkey with the muscle hemorrhage also had swollen kidneys. A third turkey, infected with TK/12582, also had swollen kidneys. Other lesions were non-specific and were consistent with anorexia and lethargy (i.e. approximately $10 \%$ of the turkeys had empty alimentary tracts). In addition, any turkeys dying or that were euthanized were necropsied, but no tissues were taken. Gross lesions were all similar to those observed in the turkeys from which tissues were collected.

Tissues were examined for microscopic lesions and viral antigen staining (Table 2 and Fig. 3). Microscopic lesions were similar among the eight birds examined, with only minor variations in severity. The most severe lesions were found in the nasal cavity, brain, heart, adrenal gland and pancreas. Moderate to severe rhinitis and sinusitis with multifocal necrosis of the nasal epithelium was common in all birds. Mild tracheitis and bronchitis, and mild to moderate interstitial pneumonia were also present. Mild to severe, randomly disseminated foci of neuronal and glial cell necrosis were observed in the cerebrum and cerebellum of all turkeys examined (Fig. 3a). Microgliosis, edema and mononuclear perivascular cuffs were also commonly observed in malacic areas of the brain. In the heart, mild to moderate multifocal myocyte necrosis was commonly observed (Fig. 3b). Moderate to severe multifocal necrosis of the pancreatic acinar epithelium was present in all birds (Fig. 2c). In the adrenal gland, mild to moderate multifocal to confluent areas of vacuolar degeneration to necrosis of corticotropic cells, and less commonly, chromaffin cells was observed in all but one turkey (Fig. 2d). Thymus, bursa and mucosa-associated lymphoid tissue had moderate to severe lymphoid depletion with apoptosis to necrosis in remaining lymphocytes (Fig. 2e). Mild to moderate depletion of the white pulp with multifocal lymphocytic necrosis was observed in the spleen. Mild to moderate necrosis of the epithelia of the Harderian glands and nasal glands was observed in most turkeys. Infrequently, the kidneys presented mild focal tubular necrosis, and the liver mild multifocal fibrinoid necrosis. Epithelial cell necrosis of the proventricular gland was observed in three turkeys. No lesions were observed in the intestine, eyelid, snood, or skeletal muscle.

Immunohistochemical staining was used to visualize virus distribution in tissues. All three viruses demonstrated similar tissue tropism where the highest levels of viral staining relative to other tissues were observed in the brain, heart, pancreas, and adrenal glands (Table 2). Staining for virus antigen was present in areas of necrosis in many tissues including brain, pancreas, adrenal gland lymphoid tissues, liver, and spleen. Virus antigen was found in parenchymal cells of organs including microglial 
Table 2 Distribution of avian influenza virus antigen visualized by immunohistochemical staining in tissues by isolate

\begin{tabular}{|c|c|c|c|c|c|c|c|c|c|c|c|c|c|c|c|c|}
\hline \multirow{2}{*}{$\begin{array}{l}\text { Bird } \\
\text { ID }\end{array}$} & \multicolumn{16}{|c|}{ Detection of avian influenza virus antigen in tissues } \\
\hline & Nasal epithelium & Nasal glands & Trachea & Lung & Heart & Brain & Liver & Kidney & Adrenal gland & Spleen & Intestine & Pancreas & Harderian gland & Thymus & Bursa & Proventric \\
\hline \multicolumn{17}{|c|}{ A/Northern Pintail/WA/40964/2014 } \\
\hline 1043 & + & + & - & + & ++ & +++ & + & + & +++ & + & + & +++ & - & - & + & - \\
\hline 1045 & + & ++ & - & + & + & +++ & - & - & +++ & - & + & +++ & ++ & ++ & + & - \\
\hline 1047 & + & + & - & + & + & +++ & + & + & +++ & + & + & +++ & + & + & ++ & + \\
\hline 1052 & + & ++ & - & + & - & +++ & + & ++ & ++ & - & - & + & & + & + & - \\
\hline 1053 & + & ++ & - & - & ++ & +++ & + & + & ++ & - & ++ & +++ & + & + & ++ & - \\
\hline 1056 & ++ & ++ & + & ++ & ++ & +++ & + & ++ & +++ & - & +++ & ++ & + & ++ & ++ & + \\
\hline \multicolumn{17}{|c|}{ A/turkey/MN/12528/2015 } \\
\hline 1093 & ++ & +++ & - & + & ++ & +++ & - & + & - & - & - & ++ & + & + & + & - \\
\hline 1097 & + & ++ & + & + & +++ & +++ & ++ & + & ++ & + & - & ++ & +++ & + & + & +++ \\
\hline \multicolumn{17}{|c|}{ A/chicken/IA/13388/2015 } \\
\hline 1040 & + & + & - & + & +++ & +++ & + & + & +++ & + & - & +++ & + & - & + & - \\
\hline 1050 & + & ++ & - & + & ++ & +++ & - & + & ++ & - & - & +++ & - & + & ++ & - \\
\hline
\end{tabular}

Turkeys were selected for examination because they were presenting with clinical illness at 4 days post challenge (DPC) (A/Northern Pintail/WA/40964/2014) or 3DPC (A/turkey/MN/12528/2015 and A/chicken/IA/13388/2015)

$-=$ no positive cells; $+=$ single positive cells; $++=$ scattered groups of positive cells $;+++=$ widespread staining

Proventric. $=$ proventriculus 


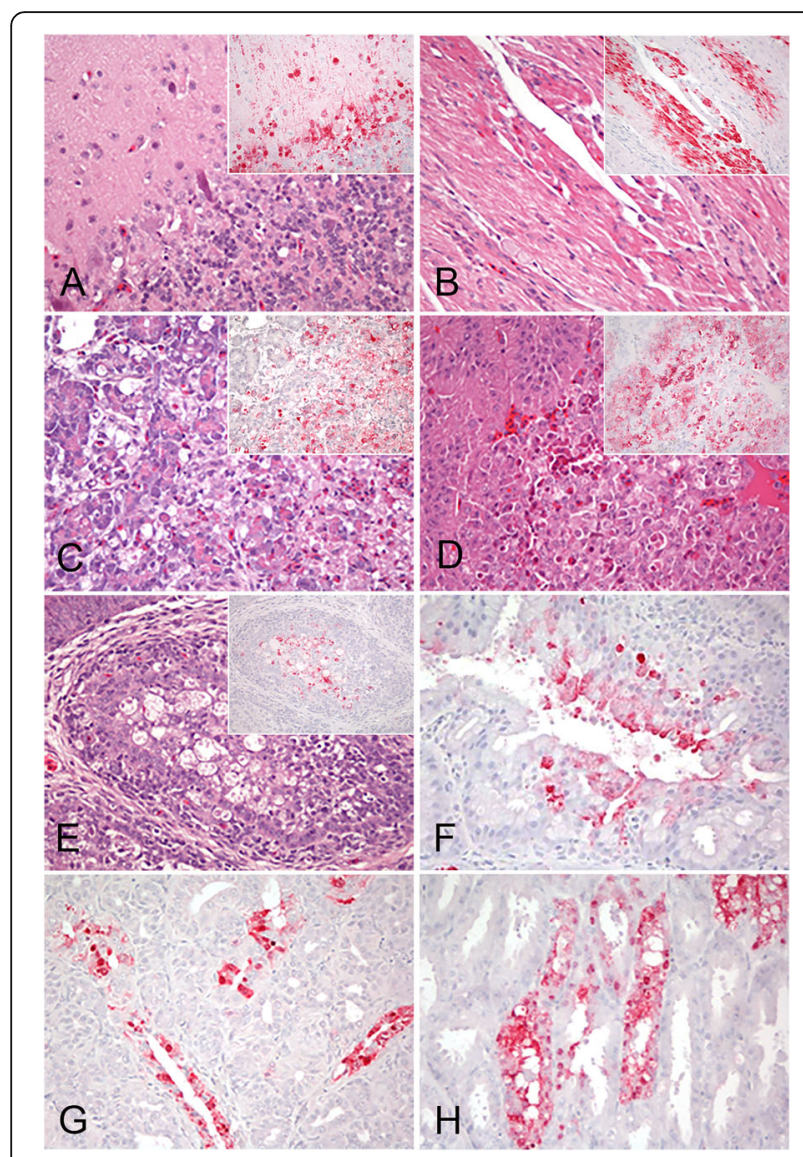

Fig. 3 Histological lesions and immunohistochemical detection of viral antigen in 4-week-old turkeys intranasally inoculated with H5N2 HPAI viruses. Tissues collected at 4 days post-inoculation. Virus antigen is stained in red. Magnifications 40x. a Cerebellum. Vacuolation of the molecular and granular layers of the cerebellum with necrosis of the Purkinge neurons. Inset: viral antigen in neurons and glial cells. $\mathbf{b}$ Heart. Focal hyalinization and fragmentation of cardiac myocytes. Inset: viral antigen in cardiac myocytes. c Pancreas. Diffuse pancreatic necrosis. Inset: viral staining in acinar epithelium. d Adrenal gland. Confluent necrosis of corticotrophic and chromaffin cells. Inset: viral antigen in adrenal corticotrophic and cromaffin cells. e Bursa de Fabricious. Lymphoid depletion with apoptosis to necrosis in remaining lymphocytes. Inset: viral antigen in phagocytic $\mathrm{c}$ and necrotic cells. f Harderian gland. Viral antigen present in epithelial cells and infiltrating phagocytes. g Nasal gland. Viral antigen present in glandular epithelial cells and infiltrating phagocytes. $\mathbf{h}$ Proventriculus. Viral antigen present in glandular epithelial cells

cells and neurons, cardiac myocytes, pancreatic acinar cells, adrenal corticotropic and chromaffin cells (Fig. 3a-d), hepatocytes, and kidney tubular epithelial cells. Viral staining was common in resident and infiltrating phagocytes of the thymus, bursa and spleen (Fig. 3e). Viral antigen was also present in epithelial cells and macrophage in the nasal turbinates, trachea, Harderian gland (Fig. 3f), nasal glands (Fig. 3g); and proventricular gland cells (Fig. 3h). No viral antigen was observed in vascular endothelial cells.

\section{Discussion}

The pathogenesis of three H5N2 HPAIV isolates from the US 2014-2015 outbreak were characterized in commercial broad breasted white turkeys. These H5N2 isolates, which were first isolated in North America in Canada, represent novel AIV reassortants with genes from Eurasian viruses: a GS/GD/96 derived HA, Eurasian PB2, PA, $M$ and NS genes, and North American wild bid virus lineage PB1, NP, NA genes [7]. The US index isolate, NOPI/40964, was selected to represent the earliest introductions detected in the US and the H5N2 HPAIV variants which are mostly likely to be adapted to wild birds. Two later isolates from the Midwest, TK/12582 and CK/13388, were selected in real-time during the outbreak to represent isolates that had likely been passaged in gallinaceous poultry based on a relatively severe clinical presentation in the field and initial epidemiological information. Based on subsequent sequence analysis and field epidemiology, the TK/12582 isolate was probably an introduction either directly from waterfowl or soon thereafter and may not have been passaged extensively in gallinaceous poultry (unpublished data). In contrast, based on the same analysis, CK/13388 may have circulated in poultry longer. This would corroborate the infectious dose data where the TK/12582 and NOPI/ 40964 isolates each required a TID $502 \log _{10}$ higher dose than the CK/13388.

In fact, the $\mathrm{TID}_{50}$ and $\mathrm{TLD}_{50}$ were the only differences observed among the three isolates. All three primarily presented with neurological signs and severe lethargy during the $24 \mathrm{~h}$ prior to death, and virus distribution among the tissues was similar. Microscopic lesions produced by all three isolates were typical for HPAIV in turkeys and other gallinaceous birds. Importantly, a high level of virus was observed in the brain by IHC, which could account for injury to the brain resulting in neurological signs.

Although the clinical presentations among all three isolates were similar, the pathogenesis of these isolates had some unusual characteristics for HPAIV. First, the MDT's, which were between 5.3 and 5.9 days, and the pre-clinical period were atypically long and mortality was distributed over a 10 day period with some turkeys dying as late as 13 days PC. By contrast, most HPAIV produce MDTs ranging between 2 and 4 days and death has been associated with replication of virus in blood vessel endothelial cells with vascular thrombosis or embolism and multi-organ failure [16, 17]. However, in this study, neural pathogenesis has been associated with direct replication of virus in neurons and neuropil support cells without vascular endothelial cells involvement, and accompanied by replication in other critical organ parenchymal cells leading to multi-organ failure, as has been shown with some previous HPAIV infections [17]. The even longer MDTs with the contact exposed turkeys 
are most likely because it took a day or two for the turkeys to become infected. Also, since the environment is artificial (e.g. grate floor isolators limiting coprophagy, high rate of airflow, etc.) the results with the contacts cannot be extrapolated directly to the field, and only provide a relative measure of transmissibility among isolates tested in similar ways.

Secondly, each of these viruses was shed at relatively high titers by the cloacal route. Highly pathogenic AIV is more often shed at the highest titers by the oral/respiratory route in gallinaceous birds [16]. It is possible that the late onset of morbidity and mortality, and high virus titers in manure contributed to the rapid spread of the virus in the Midwest, especially in light of the relatively high $\mathrm{TID}_{50}$. Essentially the turkeys are infected and are shedding substantial amounts of virus in their manure and orally as early as $24-36$ post infection for several days, but don't appear sick.

One aspect of the field situation that was not replicated in the laboratory was the age of the turkeys. During the outbreak $85 \%$ of the infected turkey flocks were at least 9 weeks of age (57\% of affected turkeys were 12 or greater weeks of age) [10]. Unfortunately, facilities which can work with HPAIV often cannot accommodate broadbreasted white turkeys in isolation cabinets over about 7 weeks of age because of their size, so it was not possible to determine if turkey age affected susceptibility for biological reasons or whether older birds have a higher chance of exposure because they have been around for a longer period of time (or a combination of both) as animal facilities with the appropriate biosafety level for floor pen studies were not available.

Relatively little data has been reported regarding experimental infection of turkeys with HPAIV and none with isolates from this lineage (clade 2.3.4.4 H5 isolates). Experimental pathogenesis studies in birds have characterized H5N8 HPAIV isolates in chickens and ducks [18-23] and the pathogenesis of NOPI/40964 H5N2 HPAIV in chickens has been reported [12]. The 50\% infectious dose in chickens was similar at $10^{5.7} \mathrm{EID}_{50}$ (versus $10^{5.0} \mathrm{EID}_{50}$ in turkeys). Notably there were differences between the pathogenesis of NOPI/40964 in chickens and turkeys: the MDT was 3 days in chickens versus 5.3 days in turkeys and the clinical presentation was also different. Neurological signs were more common in turkeys (only 1 of 10 chickens presented with neurological signs) and there were lesions unique to chickens: 1) petechial hemorrhages and cyanotic combs and wattles (turkey snoods appeared normal); and 2) infra-orbital swelling [12]. Differences in lesions between chickens and turkeys were also observed with H5N2 HPAI in the field in Canada [7] and with a 1997 H5N1 HPAIV GS/GD/96 lineage virus [24]. Similar clinical presentation (i.e. neurological signs) and gross lesions in turkeys in the field were observed in the
UK with a GS/GD/96 lineage H5N1 HPAIV [25] and with the unrelated H5N8 HPAIV in Ireland in 1983 [26]. Based on limited information from field reports, lack of respiratory signs is not uncommon in turkeys with HPAIV [7, 25, 26], although respiratory signs were reported with an H5N2 HPAIV in Italy in 1997 [27]. However, in field cases the involvement of secondary bacterial infections cannot be ruled out.

\section{Conclusions}

High mortality is the most consistent sign of HPAIV infection in turkeys as there are some biological variations in the pathogenesis of the virus. In the case of these three isolates, the long pre-clinical period, late MDT and high titers of cloacal shed are unusual characteristics and may have contributed to spread despite the initially high exposure dose to produce infection; i.e. high TID $_{50}$. Also, neurological signs were the most common clinical sign after severe lethargy observed in the turkeys, which contrasts chickens, where hemorrhagic lesions are reported more frequently. This and a shorter reported MDT in chickens highlights the difference in pathogenesis of HPAIV between chickens and turkeys. Finally, there are many other factors involved in the spread of HPAIV in poultry; attention to biosecurity should be a priority regardless of the characteristics of the lineages involved.

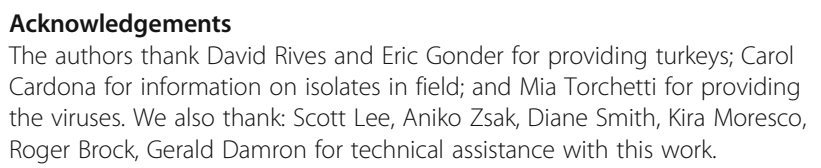

\section{Funding}

This research was supported by US Department of Agriculture, ARS CRIS Project 6612-32000-063-00D and with federal funds from the National Institute of Allergy and Infectious Diseases, National Institutes of Health, under IAA No. AAl12004-001-00001. Its contents are solely the responsibility of the authors and do not necessarily represent the official views of the $\mathrm{NIH}$. Mention of trade names or commercial products in this manuscript is solely for the purpose of providing specific information and does not imply recommendation or endorsement by the U.S. Department of Agriculture. USDA is an equal opportunity provider and employer.

\section{Availability of data and material}

The datasets during and/or analysed during the current study available from the corresponding author on reasonable request.

\section{Authors' contributions}

All authors contributed to the experimental design and editing the manuscript. ES: conducted the bird work and related lab work, and composed the manuscript. MPJ: evaluated the microscopic lesions and ran the immunohistochemistry. All authors read and approved the final manuscript.

\section{Competing interests}

The authors declare that they have no competing interests.

Consent for publication

Not applicable. 


\section{Ethics approval}

This work did not involve human subjects. All animal work was approved in advance by the Southeast Poultry Research Laboratory Institutional Animal Care and Use committee.

\section{Received: 9 July 2016 Accepted: 17 November 2016}

Published online: 22 November 2016

\section{References}

1. Testimony of Dr. Tom Elam. US Senate Committee on Agricultre, Nutrition and Forestry. Full Committee Hearing on Highly Pathogenic Avian Influenza: The Impact on the U.S. Poultry Sector and Protecting U.S. Poultry Flocks, July 7, 2015. http://www.agriculture.senate.gov/hearings/highly-pathogenicavian-influenza-the-impact-on-the-us-poultry-sector-and-protecting-uspoultry-flocks

2. Lee DH, Torchetti MK, Winker K, Ip HS, Song CS, Swayne DE. Intercontinental spread of Asian-origin H5N8 to north America through Beringia by migratory birds. J Virol. 2015;89(12):6521-4.

3. Lee DH, Bahl J, Torchetti MK, Killian ML, Ip HS, DeLiberto TJ, Swayne DE. Highly pathogenic avian influenza viruses and generation of novel reassortants, United States, 2014-2015. Emerg Infect Dis. 2016;22(7):1283-5.

4. Ip HS, Torchetti MK, Crespo R, Kohrs P, DeBruyn P, Mansfield KG, Baszler T, Badcoe L, Bodenstein B, Shearn-Bochsler V, et al. Novel Eurasian highly pathogenic avian influenza A H5 viruses in wild birds, Washington, USA, 2014. Emerg Infect Dis. 2015;21(5):886-90.

5. Kwon JH, Lee DH, Swayne DE, Noh JY, Yuk SS, Erdene-Ochir TO, Hong WT, Jeong JH, Jeong S, Gwon GB, et al. Highly Pathogenic Avian Influenza A(H5N8) Viruses Reintroduced into South Korea by Migratory Waterfowl, 2014-2015. Emerg Infect Dis. 2016;22(3):507-10.

6. Verhagen $\mathrm{JH}$, van der Jeugd HP, Nolet BA, Slaterus R, Kharitonov SP, de Vries PP, Vuong O, Majoor F, Kuiken T, Fouchier RA. Wild bird surveillance around outbreaks of highly pathogenic avian influenza $\mathrm{A}(\mathrm{H} 5 \mathrm{~N} 8)$ virus in the Netherlands, 2014, within the context of global flyways. Euro Surveill. 2015;20(12).

7. Pasick J, Berhane Y, Joseph T, Bowes V, Hisanaga T, Handel K, Alexandersen S. Reassortant highly pathogenic influenza A H5N2 virus containing gene segments related to Eurasian H5N8 in British Columbia, Canada, 2014. Sci Rep. 2015;5:9484.

8. Torchetti MK, Killian ML, Dusek RJ, Pedersen JC, Hines N, Bodenstein B, White CL, Ip HS. Novel H5 Clade 2.3.4.4 Reassortant (H5N1) Virus from a Green-Winged Teal in Washington, USA. Genome Announc. 2015;3(2): e00195-15.

9. Lee DH, Bahl J, Torchetti MK, Killian M, Ip HS, Deliberto T, Swayne DE. Asian H5N8 HPAl virus spread into North America in late 2014 and produced novel H5N1, H5N2, and H5N8 viruses by reassortment events. Emerg Infect Dis. 2016;22(7): in press

10. USDA-APHIS. Epidemiologic and Other Analyses of HPAI-Affected Poultry Flocks. September 9, 2015, Doc \#300.0615 Version 5. https://www.aphis. usda.gov/aphis/ourfocus/animalhealth/animal-disease-information/avianinfluenza-disease/ct_avian_influenza_disease. 2015

11. Pedersen JC. Hemagglutination-inhibition assay for influenza virus subtype identification and the detection and quantitation of serum antibodies to influenza virus. Methods Mol Biol. 2014;1161:11-25.

12. Bertran K, Swayne DE, Pantin-Jackwood MJ, Kapczynski DR, Spackman E, Suarez DL. Lack of chicken adaptation of newly emergent Eurasian H5N8 and reassortant H5N2 high pathogenicity avian influenza viruses in the U.S. is consistent with restricted poultry outbreaks in the Pacific flyway during 2014-2015. Virology. 2016;494:190-7.

13. Pantin-Jackwood MJ. Immunohistochemical staining of influenza virus in tissues. Methods Mol Biol. 2014;1161:51-8.

14. Reed $L$, Muench $H$. A simple method for estimating fifty percent endpoints. Am J Hyg. 1938;27:493-7

15. Spackman E. Avian influenza virus detection and quantitation by real-time RT-PCR. Methods Mol Biol. 2014;1161:105-18.

16. Swayne DE, Suarez DL, Sims LD. Influenza. In: Swayne D, editor. Diseases of poultry. 13th ed. Ames: Blackwell; 2013. p. 181-218.

17. Swayne D, Pantin-Jackwood M. Pathobiology of avian influenza virus infections in birds and mammals. In: Swayne D, editor. Avian influenza. Ames: Blackwell; 2008. p. 87-122.

18. Kanehira K, Uchida Y, Takemae N, Hikono H, Tsunekuni R, Saito T. Characterization of an H5N8 influenza A virus isolated from chickens during an outbreak of severe avian influenza in Japan in April 2014. Arch Virol. 2015;160(7):1629-43.

19. Kang HM, Lee EK, Song BM, Jeong J, Choi JG, Jeong J, Moon OK, Yoon H, Cho Y, Kang YM, et al. Novel reassortant influenza A(H5N8) viruses among inoculated domestic and wild ducks, south Korea, 2014. Emerg Infect Dis. 2015;21(2):298-304.

20. Kim YI, Pascua PN, Kwon HI, Lim GJ, Kim EH, Yoon SW, Park SJ, Kim SM, Cho EJ, Si YJ, et al. Pathobiological features of a novel, highly pathogenic avian influenza A(H5N8) virus. Emerg Microbes Infect. 2014;3(10):e75.

21. Lee DH, Kwon JH, Noh JY, Park JK, Yuk SS, Erdene-Ochir TO, Lee JB, Park SY, Choi IS, Lee SW, et al. Pathogenicity of the Korean H5N8 highly pathogenic avian influenza virus in commercial domestic poultry species. Avian Pathol. 2016;45(2):208-11

22. Lee EK, Song BM, Kang HM, Woo SH, Heo GB, Jung SC, Park YH, Lee YJ, Kim $\mathrm{JH}$. Experimental infection of SPF and Korean native chickens with highly pathogenic avian influenza virus (H5N8). Poult Sci. 2016;95(5):1015-9.

23. Song BM, Kang HM, Lee EK, Jeong J, Kang Y, Lee HS, Lee YJ. Pathogenicity of H5N8 Highly Pathogenic Avian Influenza Virus in Chickens, South Korea. J Vet Sci. 2015;16(2):237-40.

24. Perkins LE, Swayne DE. Pathobiology of A/chicken/Hong Kong/220/97 (H5N1) avian influenza virus in seven gallinaceous species. Vet Pathol. 2001;38(2):149-64.

25. Irvine RM, Banks J, Londt BZ, Lister SA, Manvell RJ, Outtrim L, Russell C, Cox WJ, Ceeraz V, Shell W, et al. Outbreak of highly pathogenic avian influenza caused by Asian lineage H5N1 virus in turkeys in Great Britain in January 2007. Vet Rec. 2007:161(3):100-1.

26. McNulty MS, Allan GM, McCracken RM, McParland PJ. Isolation of a highly pathogenic influenza virus from turkeys. Avian Pathol. 1985;14(1):173-6.

27. Capua I, Marangon S, Selli L, Alexander DJ, Swayne DE, Pozza MD, Parenti E, Cancellotti FM. Outbreaks of highly pathogenic avian influenza (H5N2) in Italy during October 1997 to January 1998. Avian Pathol. 1999;28(5):455-60.

\section{Submit your next manuscript to BioMed Central and we will help you at every step:}

- We accept pre-submission inquiries

- Our selector tool helps you to find the most relevant journal

- We provide round the clock customer support

- Convenient online submission

- Thorough peer review

- Inclusion in PubMed and all major indexing services

- Maximum visibility for your research

Submit your manuscript at www.biomedcentral.com/submit
) Biomed Central 